\title{
ゴルフスイングロボットに関する研究 ーエネルギ一制御を用いた運動軌道の生成-
}

\section{Study on Golf Swing Robot -Motion Planning Based on Energy Control-}

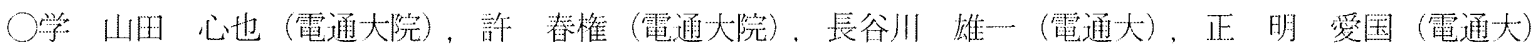

Shinya YAMADA, Chunquan XU, Yuichi HASEGAWA, Aiguo MING

The University of Electro-Communications 1-5-1 Chofugaoka, Chofu-shi,Tokyo,Japan,182-8585

\begin{abstract}
A golf swing robot which has a smart structure and enables high-speed swing based on dynamic coupling drive has been developed by authors. We have reported the feasibility of combining target dynamics and energy control to generate the golf swing trajectory from address position to impact position by now. In this paper,we apply the mehod to generate the whole swing trajectory and show its efficacy through experimental results.
\end{abstract}

Key words : golf swing robot, dynamic coupling drive, target dynamics, energy control

\section{1. 諸言}

近年，スポーツなどの高い運動仕様と高度な連動制御技 能が必哭とされる動作（以後，ハイパーダイナミックマ ニピェレーションと㭔ぶ）在ロボットで奉現するという ことが注目されている。著者らは，スポーツッなどに㧍け る人間のハイパーダイナミック動作として，ゴルフスイ ング動作を取り上げ，スマートな構造在活か子小涉駆 動による多段加速」を有効に利用した，局丽節と手首関 節の2関節からなるコルフスイングロボットを開発した。

現在，解析的方法として，ゴルフスイングロボットに エネルギ一制御在導入した目祭スイング連動軌渞を生成 する力法资研究して打り、エネルギ一制御をアドレスポ ジションからインパクトポシション交尊入していた [1]. 本稿ではアドレスポジションからつィニッシュポジショ ンまでエネルギ一制御を導入して，一連のスイング動作 学实現すること老目標としている。

\section{2. ゴルフスイングロボットのモデル}

ゴルフスイングロボットを2関節の䦌体としてモデリン グしたモデル坴图 1 に示すす.

連動力程式は冬関節に働く粘性摩擦及びクーロン摩擦 を眐視すると式 (1) と表せる。

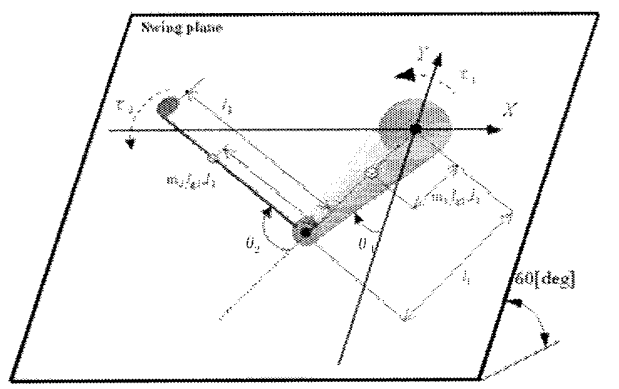

Fig.1: Model of Golf Swing Robot

$$
\begin{aligned}
& \tau_{1}=M_{11} \ddot{\theta_{1}}+M_{12} \ddot{\theta_{2}}+h_{122} \dot{\theta}_{2}^{2}+2 h_{112} \dot{\theta_{1}} \dot{\theta_{2}}+g_{1} \\
& \tau_{2}=M_{21} \ddot{\theta}_{1}+M_{22} \ddot{\theta}_{2}+h_{211}{\dot{\theta_{1}}}^{2}+g_{2}
\end{aligned}
$$

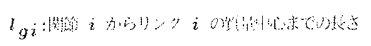

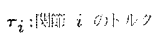

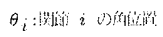

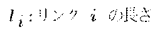

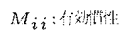

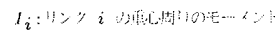

$$
\begin{aligned}
& m_{i}: \text { :リンタ }
\end{aligned}
$$

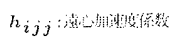

$$
\begin{aligned}
& g_{i} \text { : 似供前 }
\end{aligned}
$$

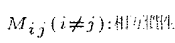

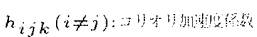

\section{3.エネルギー制御}

インパクトポジションとフィニッシュポジョンルおけ るエネルギー老目標值しし，フィードバックによりエネ ルギーを制御することで，ゴルフスイングロボットの日 標運動軌道とフィードフォワードトルク老求めること在

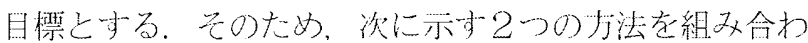
讷て、エネルギ一の日標值とスイングの境界条件を同時 满足させる。

\section{1 八ミルトニアンシステムによる制御則}

スイング連動軌道を得るために，ゴルスイングロボッ

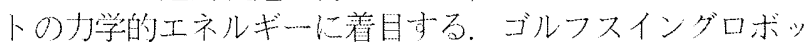
トのハミルトニアンシステムの表現式より，閉ループ系 宣满たすためのフィードバッ少制御則は式 (2)となる [1].

$$
\left[\begin{array}{c}
\tau_{1} \\
\tau_{2}
\end{array}\right]=\left[\begin{array}{c}
-K_{p} \bar{H} \dot{\theta_{1}}+K_{p} \bar{H} \dot{\theta_{2}} \\
K_{p} \bar{H} \dot{\theta_{1}}-K_{p} \tilde{H} \dot{\theta_{2}}
\end{array}\right]
$$

ただし, $\ddot{H}=H-H_{d}$

$$
H: \text { ハミルトシアン } H_{d}: \text { 甘嫩エネルギー }
$$

\section{2 目標ダイナミクスによる制御則}

日嫩ダイナミクス法 [2] とは，听望さ扎石動作をダイナ ミクスで記述し，システムがその動特性定持つように制

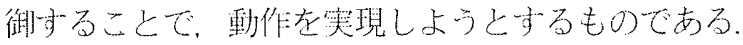

3.1 節よりゴルフスイングロボットの㠩学的エネルギー を目標值に收束させるだけでは，境界条件を洼たすスイ ング連動圶得ることを保鈔できないので，スイングの軌 道情報を目嫩ダイナミクスとして与え，ゴルフスイング ロボットの仮想エネルギ一老制御扵ることで，境界条件 を满たすスイング軌道を得ることを偝とする。

コルフスイングは振り子運動に近いことに着目し， 標ダイナミク又を調和振動とし，四２のようにコルフス

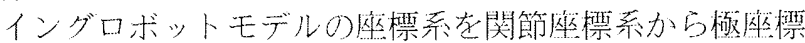
系一変換し仮想的心䍩振り子として見る。この仮想的な 振り子のエネルギーをゴルフスイン゙ロボットの仮想エ ネルギーとして尊入することで，目標ダイナミクス老式 (3)とする.

$$
\begin{gathered}
{\left[\begin{array}{c}
\dot{\theta} \\
\ddot{\theta}
\end{array}\right]=\left[\begin{array}{cc}
0 & 1 \\
-\omega^{2} & -K_{e}\left(E-E^{*}\right)
\end{array}\right]\left[\begin{array}{l}
\theta \\
\dot{\theta}
\end{array}\right]} \\
E=\frac{1}{2} \dot{\theta}^{2}+\frac{1}{2} \omega^{2} \theta^{2}
\end{gathered}
$$

$E:$ 仮整エネルボー 


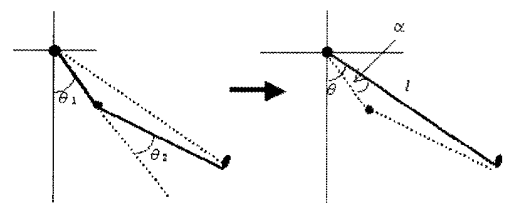

Fig.2: Transformation to imaginary pendulum

システムの出カが式 (3) の目栖ダイナミクスをもつよ うに制御するには式 (5) 老満たす必要がある [1]。式 (5) を満なすトルクの組多合わせは無数に存在する。

$a_{1} \tau_{1}+a_{2} \tau_{2}=-\omega^{2} \theta-K_{e}\left(E-E^{*}\right) \dot{\theta}+a_{3}+a_{1} N_{1}+a_{2} N_{2}$

\section{3 ロボットの制御則}

ゴルスイングロボットの制御入力 (肩関節と手首関 節のトルク) を求好るために，八ミルトニアンシステム による制御則 (式 (2)) と目標ダイナミクスによる制御則 （式 (5)）在組文合わせて使朋する。具体的には式 (2) の八 ミルトニアン $(\mathrm{H})$ を仮想エネルギー $(\mathrm{E})$ に置き換えるこ とで，屃関節のトルクを得て，式 $(5)$ に代入して手首関 節のトルクを得る。その結果，式 (6)が得られる。

$$
\begin{aligned}
& \tau_{1}=-K_{p}\left(E-E^{*}\right) \dot{\theta}_{1}+K_{p}\left(E-E^{*}\right) \dot{\theta}_{2} \\
& \tau_{2}=\frac{\left(\left(-\omega^{2} \theta-K_{\epsilon}\left(E-E^{*}\right) \dot{\theta}+a_{3}+a_{1} N_{1}+a_{2} N_{2}\right)-a_{1} \tau_{1}\right)}{a_{2}}
\end{aligned}
$$

今回は，目標エネルギ一をインパクトポジションとフィ ニッシュポシションで次式のように定義して㧍り，フィ ニッシュポジションで日標エネルギーを在達成卞ることで 制御則を切り替えずに一速のスイング軌道の生成を行う。

$$
\begin{aligned}
& E_{i}^{*}=\frac{1}{2} \frac{v^{2}}{l_{1}+l_{2}} \\
& E_{f}^{*}=\frac{1}{2} \omega^{2} \theta_{f}^{2}
\end{aligned}
$$

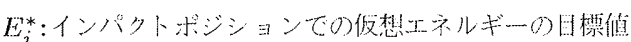

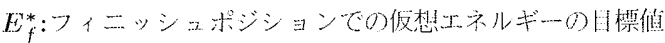
$\theta_{f}:$ フィッシュポジションでの仮想振り子の解度

\section{4. 運動軌道の生成}

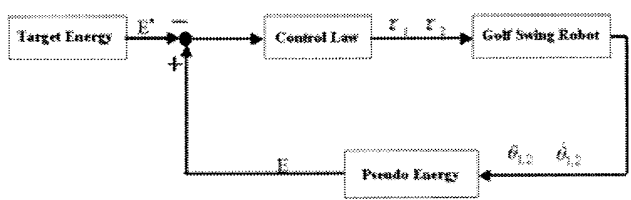

Fig.3: Generation of the reference trajectory

アドレスポジションから，フィニッシュポジションま でのスイング軌道を式 (6)の制御則に基づいて，計算扵る 流机老図 3 に示寸。式 (6) に扮いて，スイング軌道を得 るための3つのバラメータ $\omega, K_{p}, K_{e}$ 老拘束条件上境界条 件在評価関数として最適化計算によって求少る。ただし， 仮想エネルギーの目標值は，インパクトポジションまで はインパクトポジションでの伋想エネルギー，て机以降 はフィニッシュポジションでの仮想エネルギーとなって いる。目標インパクトスピード $20[\mathrm{~m} / \mathrm{s}]$ のエネルギーの 変化の様子在図 4 に示卞。

\section{5. スイング実験}

第 4. 章の方法老用いて，得られたフィードフォワードト ルクと目整スイング軌道を図 5 に示す制御系で構築され

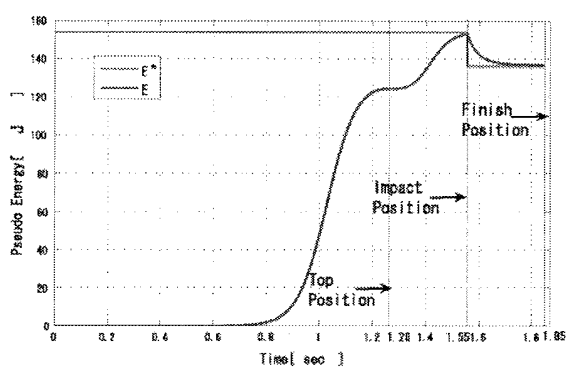

Fig.4: Change of target and current pseudo energy

ているゴルフスイングロボットに与えてスイング央験を 行った. $20[\mathrm{~m} / \mathrm{s}]$ のスイング実験結果を図 6〜図 7 に示 す。ここで、今回のケースではフィニッシュポジション での仮想层り子の角度 $\theta_{f}=\pi$ とした。

スイング実験結果より，干涉駆動を利用して目標へッ ドスピードを達成し、目標スイング軌道に精度よく追従 していることが分かる。

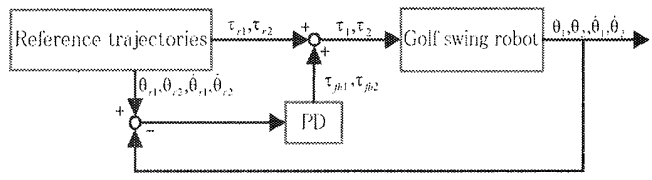

Fig.5: Control system of golf swing robot

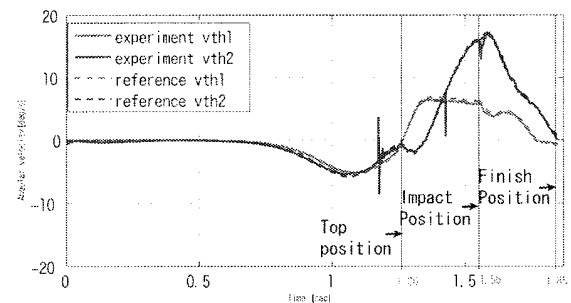

Fig.6: Experimental result : Angular velocity

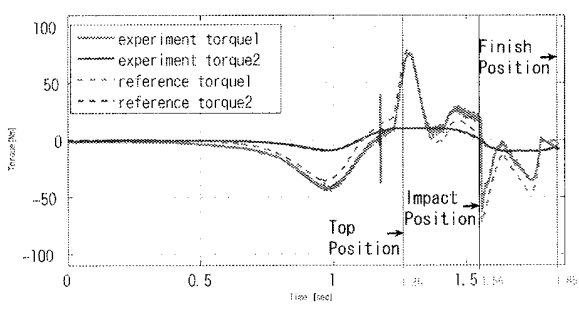

Fig.7: Experimental result : Torque

\section{6. 結言}

ゴルフスイング全過程にエネルギー制御と目標ダイナミ クスを導入することで，目標スイング軌道を生成するう 法について娭用した。また。寒験によりその有效性を確 認できた。

\section{参考文献}

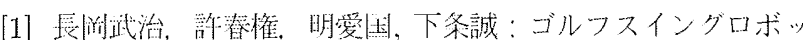

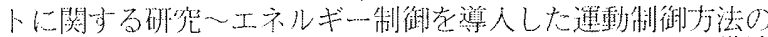

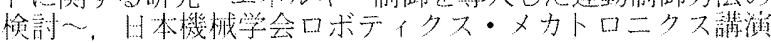
会'06，1A1-E17，(2006.5)

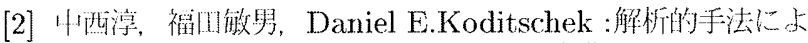
る2リンクブラキエーションロボットの例御，日本ロボット 学会袺, Vol.16,No3,pp361 368,(1998). 